Lise Togeby:

"når særlige grunde taler for, at det er til elevens bedste« - om de elever, der forlader folkeskolen i utide

Da man $i 1975$ udvidede skolepligten til 9 år, opstod der samtidig et problem med det, man kalder "de skoletrætte elever". Ikke alle børn er lige glade for at gå $i$ skole, men de fleste er dog $i$ stand til at stå de 9 års skolegang igennem. Enkelte børn befinder sig imidlertid så dårligt i skolen, at man kunne overveje, om det ikke ville være bedre for barnet selv, at komme ud af skolen og i gang med noget andet. Med henblik på sådanne situationer indeholder folkeskoleloven en dispensationsparagraf, der muligg $\varnothing \mathrm{r}$, at eleverne udskrives af folkeskolen inden afslutningen af 9 års skolegang. Folkeskoleloven af 26. juni 1975 omtaler således $i \S 33$ tre forskellige muligheder for at forlade folkeskolen:

If $\varnothing$ lge $\S 33$, stk. 2 skal "b $\varnothing \mathrm{rn}$, der følger undervisningen i en anmeldt friskole, $i$ en anerkendt privat realskole eller gymnasieskole... ikke deltage i folkeskolens undervisning. Det samme gælder elever, der efter at have gennemgået 7. klassetrin deltager $i$ kurser pà en godkendt efterskole eller husholdningsskole eller på en ungdomskostskole ..."

If $\varnothing$ lge $\S 33$, stk. 3 kan "undervisningspligten endvidere efter det 7 . klassetrin opfyldes ved deltagelse $i$ heltidsundervisning $i$ den kommunale ungdomsskole ..."

Og endelig ifølge $\S 33$, stk. $4 \mathrm{kan}$ "skolenævnet efter forældrenes anmodning tillade, at en elev efter 7 ås undervisning helt eller delvis opfylder undervisningspligten ved at deltage $i$ erhvervsmæsig uddannelse eller beskæftigelse, når særlige grunde taler for, at det er til elevens bedste."

Sxrlig den sidste regel blev meget diskuteret omkring vedtagelsen af den nye skolelov. Mange frygtede, at det ikke blev elevens eget bedste, der blev afgørende for, om der blev foretaget udskriv- 
ninger efter $\S 33$, stk. 4, men snarere forældrenes $\phi$ nsker eller hensynet til de andre elever.

De fleste kan blive enige om, at det næppe er nogen god løsning, at man udskriver nogle af de skolemæssigt dårligst funderede elever efter kortere tids skolegang end de normalt funderede elever. I de seneste år er der derfor på forskellig vis blevet eksperimenteret med skoleformer, hvor man kombinerer undervisning med praktisk arbejde. På denne måde forsøger man at få skabt nogle undervisningstilbud, der appellerer til de elever, der befinder sig dårligt $i$ den almindelige folkeskole.

Debatten omkring anvendelsen af $\S 33$ præges af en række overvejelser om, hvorledes det går disse elever senere hen i livet. Argumentationen for udskrivningen vil i det enkelte tilfælde of te være, at eleven befinder sig dårligt $i$ den bogligt pragede folkeskole, hvilket kombineres med det fromme håb, at han eller hun vil f $\phi$ le sig bedre tilpas med erhvervslivets praktiske krav. Kritiske røster fremhæver i modsætning hertil, at netop de skolemæssigt svagt funderede elever også vil komme til kort uden for skolen, hvor de skal konkurrere med bedre uddannede kammerater om uddannelsespladser og arbejdspladser.

Egentligt er det meget lidt, man ved om, hvorledes det går disse $\S 33$-elever, efter at de har forladt folkeskolen. Men der eksisterer vel nok en generel fornemmelse af, at det ikke går dem særlig godt.

De unders $\varnothing$ gelser, der hidtil er blevet foretaget omkring $\S 33-$ eleverne, har koncentreret sig om at beskrive, hvad det er for elever, der bliver udskrevet inden afslutningen af de 9 års skolegang. Det er således blevet påvist, at der udskrives flere drenge end piger, at der ofte udskrives børn af ufaglærte arbejdere og af enlige mødre, at de udskrevne børn ofte har haft indlæringsproblemer, og at der endelig of te er tale om elever med ringe selvtillid, ringe evne til samarbejde og dårlig kammeratkontakt. De fleste af de her omtalte unders $\phi$ gelser lider imidlertid metodisk set af $i$ det mindste to svagheder. For det f $\phi$ rste omfatter hver af disse unders $\phi$ gelser et meget begrænset antal elever, og for detandet erdet gennemgående ikke muligt at sammenligne oplysningerne om $\S 33$-eleverne med tilsvarende oplysninger om normalelever. Dertil kommer som tidligere omtalt, at man sjældent har oplysninger om, hvordan det videre 
er gået eleverne, efter at de blev udskrevet af folkeskolen. ${ }^{1}$

Denne artikel vil meddele resultaterne fra en undersøgelse, der har været således tilrettelagt, at man kommer ud over nogle af de nævnte problemer. Ganske vist indgår der heller ikke i denne unders $\phi$ gelse noget stort antal $\S 33$-elever. Alt i alt omfatter unders $\phi$ gelsen'177 §33-elever, hvoraf 104 elever er udskrevet til erhvervsmæssig uddannelse eller beskæftigelse. Til gengæld indgår disse 177 elever $i$ en totalunders $\phi g e l s e$ af en hel årgang elever fra Århus kommunale skolevæsen, omfattende $i$ alt 2693 elever. Det vil således være muligt at foretage sammenligninger mellem $\S 33$-eleverne og de normale folkeskoleelever. Videre forholder det sig sådan, at undersфgelsen inddrager oplysninger om, hvorledes det er gået eleverne, efter de forlod folkeskolen, indsamlet omkring to år efter udskrivelsen. ${ }^{2}$

ved hjælp af det indsamlede materiale vil det være muligt at belyse tre forskellige spørgsmål. For det første spørgsmålet om omfanget af udskrivelserne. For det andet spørgsmålet om hvem det er, der bliver udskrevet. Og endelig for det tredie spørgsmålet om, hvorledes det går eleverne, efter at de har forladt folkeskolen.

\section{Materialets sammensætning}

Det største problem $i$ forbindelse med denne unders $\phi$ gelse har været overhovedet at få identificeret de elever, der var blevet udskrevet efter $\S 33$. Med hensyn til de elever, der bliver udskrevet til erhvervsmæssig uddannelse eller beskæftigelse, har skolenævnene ganske vist en forpligtelse til at indberette udskrivelsen til undervisningsministeriet. Dels er det imidlertid langt fra sikkert, at alle udskrivninger bliver indberettet. Dels findes tilsvarende regler ikke for de to andre former for udskrivning.

1) Den hidtil mest omfattende undersøgelse af $\S 33$-eleverne er foretaget af Rona Petersen og Pierre Topaz, idet de har undersøgt 281 sảdanne elever. (Rona Petersen og Pierre Topaz, Drop-outs, Rapport nr. 1 og Rapport nr. 2, Danmarks

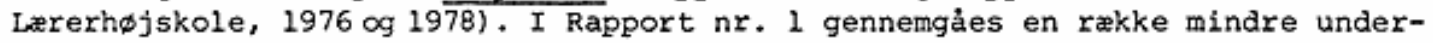
sфgelser, der fortrinsvis er gennemført i forbindelse med studier pá lærerhøjskolen.

2) Artiklen meddeler sảledes nogle delresultater fra en større forløbsundersøgelse. Tidligere er der i forbindelse med undersøgelsen blevet publiceret: Lise Togeby, Midtvejsrapport fra en undersøgelse af problemer $i$ forbindelse med overgang fra skole til erhverv, Institut for Statskundskab, 1978. Hele undersøgelsen forventes afsluttet med en samlende rapport i løbet af 1980 . Unders $\phi-$ gelsen er igangsat og finansieret af Arhus kommune. 
I denne unders $\varnothing$ gelse er "§ 33-eleverne" blevet defineret som de elever, der efter afslutningen af 7 års skolegang, men inden afslutningen af 9 års skolegang, udskrives enten til andre skoleformer (privatskoler, efterskoler, m.m.), til heltidsundervsining i ungdomsskolen eller til erhvervsmæsig uddannelse eller beskæftigelse. $\S$ 33, stk. 2 anvendes også til at udskrive elever fra folkeskolen til privatskoler og friskoler inden for de første 7 skoleår, men sådanne udskrivninger er ikke inddraget $i$ denne unders $\varnothing$ gelse.

Identifikationen af $\S 33$-eleverne tog udgangspunkt i kommunens såkaldte bestandsskemaer over elever på 8. og 9. klassetrin. På grundlag af bestand skemaerne var det muligt at identificere omkring 250 elever, der inden afslutningen af 9 . skoleår var blevet udskrevet af skoler i Århus kommune. En del af disse elever var imidlertid blot flyttet fra en af kommunens skoler til en anden. Om andre elever gjaldt det, at de havde gået flere år i samme klasse og således reelt havde gået 9 år $i$ skolen, selv om de blev udskrevet inden afslutningen af 9. klasse. På grundlag af oplysningerne fra udskrivningsskolerne blev begge disse grupper af elever fjernet fra det oprindelige materiale. Den således udarbejdede liste over udskrevne elever blev derefter sammenlignet med den eksisterende liste over elever, der ifølqe skolernes indberetninger var udskrevet til erhvervsmæssig beskæftigelse efter $\S 33$, stk. 4. Alt i alt blev der identificeret 177 elever, der i skoleåret 1976-77 var blevet udskrevet efter en af de tre dispensationsregler i $\S 33$.

Den anvendte procedure medf $\varnothing$ rte desværre, at to mindre grupper af elever, der egentlig burde være inddraget $i$ unders $\varnothing$ gelsen, ikke blev det. Det drejer sig for det første om nogle få elever, der har gået en klasse om, og som derefter er blevet udskrevet af folkeskolen, mens de endnu gik i 7. klasse, men altså efter afslutningen af 7 års skolegang. Skønsmæssigt har der været tale om 5-7 elever, der hovedsagelig er blevet udskrevet til heltidsundervisning $i$ ungdomsskolen. 3 Man kan kun beklage, at det ikke er lykkedes at identificere disse elever. Det drejer sig for det andet om nogle elever, der efter at have afsluttet de første 7 års skolegang $i$ folkeskolen har fortsat deres skolegang på privatskoler eller efterskoler. Hvis denne overgang er sket umiddelbart efter afslutningen af 7 . klasse,

3) Dette skøn bygger pá oplysninger fra skolevæsenet og fra ungdomsskolen. 
har disse elever ikke optrådt på skolevæsenets bestandsskemaer for elever i 8. - 9. skoleår. Det er vanskeligt præcist at vurdere, hvor mange elever der er tale om, men det er antagelig en 10-15 stykker. ${ }^{4}$ Det vil hovedsagelig være elever, der kommer fra skolen med kun 7. klassetrin, hvorfor disse elever under alle omstændigheder skulle skifte skole efter 7. klasse. Nogle elever vælger i denne situation andre skoleformer end folkeskolen. Motivet hertil vil sjældent være vanskeligheder $i$ forhold til folkeskolen, men snarere familiemæssige traditioner eller privatskolens geografiske nærhed. Disse elever er således formelt udskrevet efter $\S 33$, stk. 2, men reelt hører de egentlig ikke til blandt $\$ 33$-eleverne. I relation til unders $\emptyset$ gelsens problemstilling er det derfor ikke nogen større ulykke, at det ikke er lykkedes at identificere denne sidste gruppe af elever. Men det har naturligvis betydning for vurderingen af det samlede antal udskrivninger.

Alt i alt kan man om den anvendte procedure konkludere, at den har sikret en rimelig præcis registrering af de elever, der blev udskrevet til erhvervsmæsig uddannelse eller beskæftigelse. Undervisningsministeriet og Århus kommune havde på forhånd registreret 72 elever. Ved den anvendte procedure lykkedes det at identificere yderligere 32 elever, hvilket resulterede $i$ en registrering af $i$ alt 104 elever udskrevet til erhvervsmæsig uddannelse eller beskæftigelse. Derimod medførte den anvendte metode nok, at man ikke fik registreret alle de elever, der blev udskrevet til andre skoleformer og til heltidsundervisningen $i$ ungdomsskolen. Sammenlagt drejer det sig antagelig om noget $i$ retning af 20 elever, der ikke er blevet registreret. Dette betyder, at det samlede antal udskrivninger i Århus kommune efter $\S 33$ for skoleåret 1976-77 summerer op til små 200 elever.

Til de omtalte 177 udskrevne elever blev der i december 1978 udsendt et spørgeskema, hvor de tidligere elever blev spurgt om deres фjeblikkelige beskæftigelse, og om hvorledes det $i$ фvrigt var gået dem, efter at de havde forladt folkeskolen. Samtidig blev der indhentet en række oplysninger om eleverne fra deres respektive skoler. Da svarprocenten endnu efter tre rykkerskrivelser var lavere end man

4) Dette skøn bygger pàoplysninger fra skolevæsenet om de vurderinger skolerne hvert àr i januar måned foretager vedrørende antallet af elever, der ikke venter at fortsætte fra 7 . klasse til 8. klasse inden for kommunens skoler. 
kunne ønske, besluttedes det at opsøge eleverne på deres bopæl. Dette bet $\phi d$, at indsamlingsperioden kom til at strække sig over lidt over to måneder. Til gengæld lykkedes det at opnå en sả pæn svarprocent som 80 pct., idet der blev indsamlet spørgeskemaer fra 141 af de oprindelige 177 elever.

Samtidig med spørgeskemaerne til $\S 33$-eleverne blev der udsendt spørgeskemaer til alle andre elever, der var udskrevet af Århus skolevæsen $i$ skoleåret 1976-77. Det drejede sig om de elever, der var udskrevet ved afslutningen af 9 . skoleå $i$ lфbet af 10 . skoleår og ved afslutningen af 10. skoleår. Alt i alt deltog 2516 tidligere elever $i$ denne del af undersøgelsen. Den samlede svarprocent var 85 pct. For disse elevers vedkommende var der tidligere blevet indsamlet oplysninger om skoleforløbet. 5

\section{2. §33-udskrivningernes samlede omfang}

Der findes ikke nogen samlet opgørelse over, hvor mange elever der for landet som helhed udskrives efter $\S 33 .{ }^{6}$ Men som næunt skal der ske en indberetning til undervisningsministeriet, hver gang der udskrives en elev til erhvervsmæssig uddannelse eller beskæfigelse efter $\S 33$, stk.4. Antallet af indberetninger for tiden efter den nye folkeskolelov trådte $i$ kraft er for landet som helhed opgjort i tabel $1 .^{7}$

Som det fremgår af tabel 1 , er antallet af indberetninger steget fra 1914 i skoleåret 1975-76 til 2428 i skoleåret 1978-79. Om dette er udtryk for en reel stigning eller blot for en mere effektiv registrering, er det vanskeligt at sige noget om. Under alle omstændigheder kan man gå ud fra, at det faktiske antal udskrivninger er større end antallet af indberetninger til undervisningsministeriet.

5) Det er Arhus kommunes skolevæsen, der har stået for det praktiske arbejde $i$ forbindelse med indsamling af spørgeskemaerne. Materialet er kodet af stud.scient. pol. Gunnar Jørgensen og stud.scient,pol. Jørgen Swensen. Endelig er EDB-arbejdet udført af cand.scient.pol. Karen Mogensen og cand.scient.pol. Kaj Nørrehede Christensen.

6) Vedrørende heltidsundervisningen i ungdomsskolen er der netop udarbejdet en rapport fra Voksenpædagogisk Center, Arhus amt. Af denne rapport fremgår det, at der i skoleảret 1976-77 for landet som helhed blev undervist 275 elever $i$ den skolepligtige alder under ungdomsskolernes heltidsundervisning. Tallet er for skoleăret 1978-79 steget til 598 elever. (Ivan Hăuser m.fl. (red.), Heltidsundervisning $i$ ungdomsskolen, Arhus 1979).

7) Tallene er stillet til rådighed af Direktoratet for Folkeskolen. 
Tabel 1. Antallet af udskrivninger efter $\S 33$, stk. 4 for hele landet inden for de sidste år

\begin{tabular}{ll}
\hline $1975 / 76$ & 1914 \\
$1976 / 77$ & 2283 \\
$1977 / 78$ & 2348 \\
$1978 / 79$ & 2428 \\
\hline
\end{tabular}

Afspejler forholdene $i$ Århus kommune forholdene $i$ resten af landet, vil det sige, at lidt over en fjerdedel af det samlede antal udskrivninger ikke er registreret. Overført til landsplan betyder det, at det samlede antal udskrivninger til erhvervsmæssig beskæftigelse og uddannelse for skoleåret 1976-77 antagelig nærmer sig 3.000 elever eller omkring $4 \frac{1}{2}$ pct. af en årgang elever.

Den her foretagne unders $\phi$ gelse begrænser sig til eleverne inden for Arhus kommunale skolevæsen. Tabel 2 angiver det absolutte antal udskrivninger samt udskrivningerne $i$ procent af en hel afgangsårgang, nemlig den årgang, der forlod Århus skolevæsen i skoleåret $1976-77 .^{8}$

Tabel 2. Det samlede antal udskrivninger efter $\S 33$ i Århus kommune i skoleåret 1976-77

\begin{tabular}{lcc}
\hline & Antal & Pct. af afgangsärg. \\
\hline 33-elever & 177 & 78 \\
heraf $\S 33$, stk. 4 & 104 & 48 \\
\hline
\end{tabular}

Af tabellen fremgår det, at der $i$ skoleåret $1976-77$ blev udskrevet 104 elever til erhvervsmæsig uddannelse eller beskæftigelse, hvilket svarer til 4 pct. af hele årgangen. Tilsammen er der efter de tre dispensationsregler blevet udskrevet 177 elever eller omkring 7 pct. af hele årgangen. Taqer man hensyn til, at ikke alle udskriv-

8) En afgancsàrgang er defineret som alle de elever, der forlader folkeskolen et givet år, i dette tilfælde i skoleàret 1976-77. Afgangsảrgangen bestăr af de elever, der har forladt folkeskolen efter afslutningen af 9 . klasse, $i$ løbet af 10. klasse, ved afslutningen af 10 . klasse, samt af $\S 33$-eleverne. En afgangsảrgang har nogenlunde same størrelse som de ảrgange, der begyndte $i \mathrm{l}$. klasse 9-10 ảr tidligere. Det er begrebet om en afgangsárgang, der har dannet udgangspunkt for hele den forløbsundersøgelse, som $\S 33$-undersøgelsen er en del af. 
ninger til andre skoleformer er blevet registreret, får man en samlet udskrivningsprocent for alle former for udskrivning på omkring 8 pct. Dette betyder, at der i gennemsnit for hele kommunen udskrives omkring ën elev pr. klasse til erhvervsmæssig beskæftigelse eller uddannelse og yderligere omkring én elev til andre skoleformer.

Man kan se meget varierende procenttal, når der foretages opg $\emptyset$ relser over $\S 33$-udskrivningerne. Årsagen hertil er først og fremmest, at der råder stor uklarhed med hensyn til, hvilke bestandstal man skal sætte udskrivningerne $i$ forhold til. Således ser man ofte, at det enkelte års udskrivninger sættes $i$ forhold til det samlede antal elever på 8 . og 9. klassetrin eller endog $i$ forhold til det samlede antal elever på 7., 8. og 9. klassetrin. ${ }^{9}$ Tankegangen bagved er $\varnothing$ jensyrilig den, at eleverne udskrives af henholdsvis to eller tre klasser. Ved denne beregningsmade kommer man imidlertid til at undervurdere omfanget af $\S 33$-udskrivningerne. Det interessante må være at få at vide, hvor stor en andel af en årgang, der udskrives på dispensation. Et nogenlunde rigtigt mål herfor får man, hvis man et givet år sætter antallet af udskrivninger efter $\S 33$ i forhold til det samlede antal elever, der udskrives af skolen det pågædende år. Det er denne beregningsmåde, der ligger til grund for tabel 2 .

Lad os derefter se på, hvad det er disse 8 pct. af eleverne udskrives til. I tabel 3 er alle $\S 33$-elever opdelt efter, hvad de lavede umiddelbart efter udskrivelsen. Opgørelsen bygger hovedsagelig på skolernes oplysninger, men hvor disse mangler, på elevernes egne oplysninger.

Det fremgår af tabellen, at 57 elever er udskrevet til andre skoleformer, herunder 24 til privatskolerne of 33 til efterskoler, ungdomsskoler, ungdomskostskoler eller husholdningsskoler. 10 elever blev udskrevet til heltidsundervisning $i$ Ungdomsskolen på sct. Annaqade. ${ }^{10}$ Endelig blev 104 elever udskrevet til erhvervslivet,

9) Se f.eks. Rona Petersen og Pierre Topaz, Drop-outs, Rapport nr. 2, Danmarks Lxrerhøjskole, 1978.

10) Af rapporten on heltidsundervisningen $i$ ungdomsskolen fremgảr det, at der $i$ skoleảret 1976-77 startede 26 elever pả Sct. Annagade. Differencen mellem de $10 \mathrm{og}$ de 26 elever fremkomer ved at nogle af ungdomsskolens elever allerede på et tidliqere tidspunkt var blevet udskrevet af folkeskolen, mens andre var over den skolepligtige alder. Endelig gik der ogsả pả Sct. Annagade, som tidligere omtalt, nogle fả elever, der var udskrevet i lobet af 7 . klasse, men efter afslutningen af 7 árs skolegang. (Ivan Hăuser m.fl. (red.), Heltidsundervisningen $i$ ungdomsskolen, Arhus 1979, p. 136). 
Tabel 3 . Arten af udskrivninger efter $\S 33$ i Arhus kommune, skoleåret 1976-77

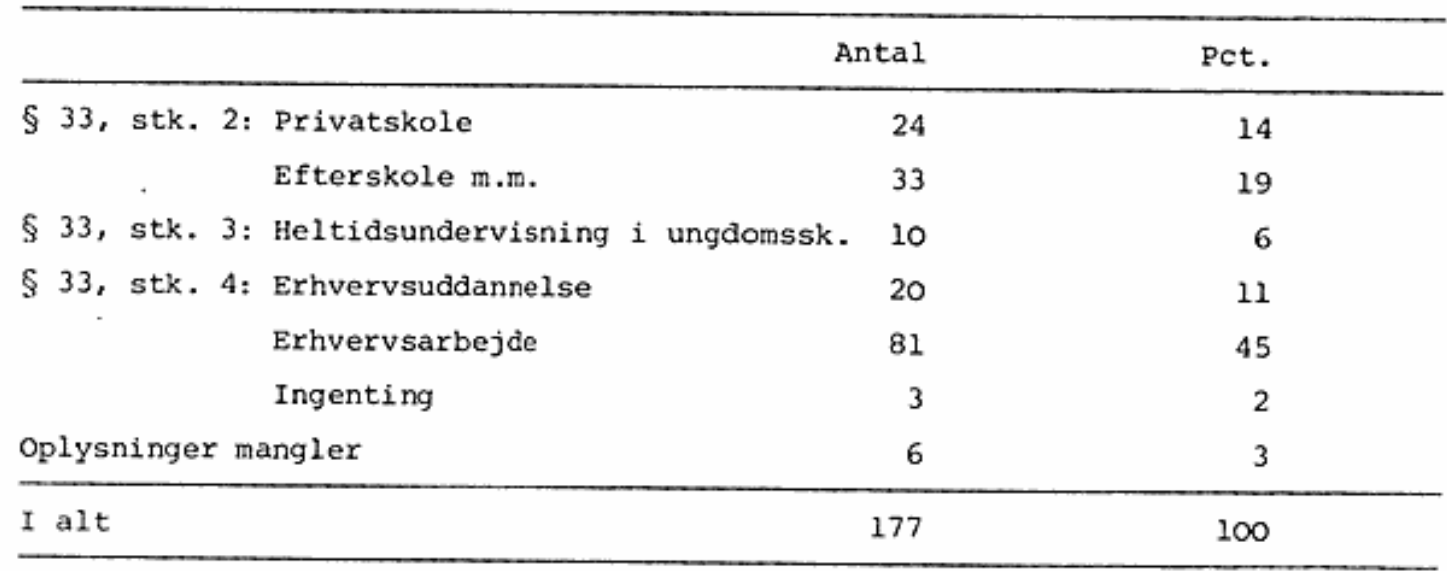

heraf 20 til en erhvervsuddannelse, 81 til et ufaglært arbejde af den ene eller anden art, medens 3 elever hverken kom $i$ gang med en uddannelse eller et arbejde. For 6 elevers vedkommende mangler der oplysninger om, hvad de er udskrevet til.

Vigtigt er det at bemærke, at kun omkring 20 pct. af de elever, der blev udskrevet til erhvervsmæssig uddannelse eller beskæftigelse, ved udskrivningen kom $i$ gang med en erhvervsuddannelse. Resten begyndte på forholdsvis fremtidsløse ufaglærte jobs. For 84 elevers vedkommende dispenseres der altså for undervisningspligten, uden at der iværksættes et andet undervisningsforløb.

Det viser sig i фvrigt, at der er forskel pá, hvornår i skoleforløbet udskrivningerne sker, alt efter om udskrivningen foretages til den ene eller den anden form for aktivitet. Tabel 4 viser tids-

Tabel 4. § 33-eleverne i Århus kommune 1976-77, opdelt efter udskrivelsestidspunkt og udskrivningens art. Procent

\begin{tabular}{|c|c|c|c|c|c|c|}
\hline & Alle & $\begin{array}{l}\text { Privat- } \\
\text { skole }\end{array}$ & $\begin{array}{l}\text { Efter- } \\
\text { skole }\end{array}$ & $\begin{array}{l}\text { Heltidsund= } \\
\text { i ungdsk. }\end{array}$ & $\begin{array}{l}\text { Erhvervs- } \\
\text { uddan. }\end{array}$ & $\begin{array}{l}\text { Arbej- } \\
\text { de }\end{array}$ \\
\hline $\begin{array}{l}\text { Slutning af } 7 . \mathrm{kl} \text {. } \\
\text { I løbet af eller } i\end{array}$ & 5 & 4 & 3 & 0 & 0 & 8 \\
\hline slutningen af $8 . \mathrm{kl}$. & 41 & 46 & 58 & 90 & 15 & 37 \\
\hline I løbet af $9 . \mathrm{kl}$. & 54 & 50 & 39 & 10 & 85 & 55 \\
\hline I alt & 100 & 100 & 100 & 100 & 100 & 100 \\
\hline
\end{tabular}


punktet for udskrivningen, dels for alle udskrivninger samlet, dels særskilt for hver art af udskrivning. Gennemgående sker udskrivning til andre skoleformer på et noget tidligere tidspunkt end udskrivning til erhvervsmassig uddannelse eller beskæftigelse. Specielt sker udskrivning til heltidsundervisningen $i$ Ungdomsskolen på Sct. Annagade tidligt, som regel $i$ løbet af 8 . klasse. Senest sker udskrivning til erhvervsuddannelse, idet hele 85 pct. af disse elever først udskrives $i$ løbet af 9 . klasse. Dette sidste kan have to årsager. Dels kan det skyldes, at mestrene ikke tager lærlinge, der er meget yngre end 16 år, dels kan det skyldes, at disse udskrivninger adskiller sig noget fra de andre udskrivninger til erhvervslivet. Man kan tænke sig, at motivet til udskrivningen snarere er, at der foreligger et tilbud om en læreplads, end at der er vanskeligheder med skolen.

Det er muligt på grundlag af skolernes indberetninger til undervisningsministeriet at sammenligne disse tal for Ârhus kommune med tal for resten af landet. Tabel 5 angiver til sammenligning med Århus kommune, hvor stor udskrivningsprocenten efter $\S 33$, stk. 4 er for hele landet amt for en række udvalgte amter. Samtidig er angivet, hvor stor en del af de således udskrevne elever, der blev udskrevet til en erhvervsuddannelse. For at give et rimeligt sammenligningsgrundlag er der også for Århus kommune regnet med de tal, der fremgår af indberetningerne til undervisningsministeriet. ${ }^{11}$

Tabel 5. Udskrivningerne $i$ Århus kommune sammenlignet med udskrivningerne 1 resten af landet. Skoleåret 1976-77

\begin{tabular}{lcc}
\hline & $\begin{array}{l}\text { Pct. udskrevet efter } \xi 33, \\
\text { stk. } 4 \text { (sat i forhold til } \\
\text { antallet af elever pä 9. } \\
\text { klassetrin) }\end{array}$ & $\begin{array}{l}\text { vet til erhvervsmæssig uddan- } \\
\text { nelse }\end{array}$ \\
\hline Arhus kommune & 2,8 & 22 \\
Resten af Arhus amt & 3,3 & 25 \\
Københavns kommune & 1,9 & 48 \\
Københavns amt & 1,5 & 49 \\
Ringkøbing amt & 3,6 & 22 \\
Hele landet & 3,3 & 31 \\
\hline
\end{tabular}

11) Tallene er stillet til rådighed af Direktoratet for folkeskolen. 
If $\varnothing$ lge undervisningsministeriets opg фrelser er der i Århus kommune udskrevet 2,8 pct. af eleverne efter $\S 33$, stk. 4, hvilket er en smule under landsgennemsnittet på 3,3 pct. Århus kommune ligger videre lidt lavere end resten af Århus amt, ligesom den ligger lavere end Ringkøbing amt. Til gengæld ligger Århus kommune en del højere end både Københavns kommune og Københavns amt, hvilket umiddelbart må undre. Endnu klarere fremtræder de geografiske forskelle, når man ser på, hvor stor en andel af $\S 33$, stk. 4-eleverne, der udskrives til en eller anden form for erhvervsuddannelse. Århus kommune ligger her klart under landsgennemsnittet og meget langt under Københavns kommune og Københavns amt. Dette må man have in mente, når man generaliserer resultaterne af denne unders $\emptyset$ gelse til at gælde hele landet.

De tal, der hidtil er blevet vist, både for Århus kommune og for landet som helhed, er tallene for de elever, der officielt udskrives af folkeskolen efter dispensationsparagraffen, $\S 33$. Hermed har man imidlertid ikke optalt alle de elever, der reelt forlader folkeskolen med mindre end 9 års undervisning bag sig. For det første er der nogle elever, der ikke engang når at gennemf $\phi$ re de f $\phi$ rste 7 års undervisning $i$ folkeskolen, først og fremmest fordi deres skolegang har været præget af voldsomme adfærdsproblemer. Nogle er således blevet overf $\phi$ rt til særlige observationsskoler, og andre har fåt etableret eneundervisning. Der er ikke tale om særlig mange elever om året, men der er dog tale om nogle stykker.

For det andet er der den gruppe elever, som Rona Petersen og Pierre Topaz $i$ en undersфgelse har kaldet "camouflerede drop-outs", altså elever, der formelt set stadig f $\phi$ lger folkeskolens undervisning, men som reelt er ophørt dermed. ${ }^{12}$ Dette fænomen kan antage forskellige former. Det vil således senere blive påvist, at der er betydelige forskelle mellem forskellige skoler $i$ henseende til den villighed, hvormed de udskriver elever efter $\S 33$. Nogle skoler vælger at tilbyde eleverne en udvidet erhvervspolitik frem for at udskrive dem. Fordelen herved er, at eleven stadigvæk har tilbudet om om at komme tilbage til sin gamle klasse, og at skolen kan føre kontrol med kvaliteten af elevens beskæftigelse. Men reelt vil eleven

12) Rona Petersen og Pierre Topaz, op.cit., pp. 13-14. 
of te have forladt folkeskolen lige så effektivt, som hvis han eller hun var udskrevet efter $\S 33$. Endelig eksisterer der $i$ folkeskolen det problem, at nogle elever bare bliver væk fra undervisningen. Der er utvivlsomt forskel på, hvor hurtigt skolerne reagerer på dette fænomen. Forekommer skulkeriet i slutningen af 9 . klasse, vil tilskyndelsen til at gøre noget ved det antagelig være forholdsvis ringe. Også her findes en gruppe af unge, der reelt er ophфrt med at følge folkeskolens undervisning.

Det kan være vanskeligt præcist at opgøre omfanget af disse "camouflerede drop-outs", men Petersen og Topaz skønner på grundlag af en række mindre unders $\varnothing$ gelser, at de of te udg $\varnothing \mathrm{r}$ op mod en trediedel af de elever, der formelt udskrives efter $\S 33 .{ }^{13}$ og lægger man endelig de camouflerede skoleophør til de formelt registrerede, når man frem til, at omkring 10 pct. af en elevårgang ophører med at $f \varnothing l g e$ folkeskolens undervisning inden afslutningen af 9 års skolegang.

De "camouflerede drop-outs" er i фvrigt ikke blevet inddraget $i$ denne unders $\varnothing$ gelse og vil ikke blive omtalt yderligere. Men det er værd at erindre sig, at visse forskelle, eksempelvis mellem enkelte skoler kan være udtryk for en større eller mindre vilje til at formalisere reelle forhold.

\section{Hvem er det, der udskrives?}

Der er vel især to grunde til, at man interesserer sig for, hvad det er for elever, der udskrives efter $\S 33$. Den ene grund er, at man gerne vil vide, hvor stor den sociale skævhed er i forbindelse med denne afskrælning af elever fra skolesystemet. Den anden grund er, at en viden om, hvad det er for børn, der udskilles af folkeskolen, kan bruges til at forebygge fremtidige udskrivninger gennem iværksættelse af støtteforanstaltninger på et tidligt tidspunkt. Disse to interesser vil også ligge bag de følgende overvejelser.

Det er drenqene, der har de største problemer $i$ folkeskolen. Som man kan forvente, er der derfor også flere drenge, der udskrives af folkeskolen inden skolepliqtens oph $\phi$ r. I tabel 6 er der foretaget en sammenligning mellem på den ene side $\S 33$-eleverne og på den anden side hele afgangsårgangen $i$ henseende til $k \not \varnothing n$. Tabellen viser,

13) Ibid., pp. 13-14. 
Tabel 6. Sammenligning mellem $\S 33$-eleverne og hele afgangsårgangen 1976-77 i henseende til $k \not n$. Procent

\begin{tabular}{lcc}
\hline & $\$ 33$-elever & Afgangsảrgangen \\
\hline Drenge & 67 & 50 \\
Piger & 33 & 50 \\
\hline I alt & 100 & 100 \\
\hline Gruppernes størrelse & 177 & 2693 \\
\hline
\end{tabular}

at en trediedel af de udskrevne elever er piger, mens hele to trediedele er drenge. Udskrivningen efter $\S 33$ bliver for nogle drenge den forudsigelige afslutning på et skoleforløb fyldt med problemer. Allerede $i$ de første skoleår har drengene oftere indlæringsproblemer, og de har oftere adfærdsproblemer.

Kønsforskellene varierer imidlertid mellem de forskellige udskrivningsformer. I tabel 7 er $\S 33$-eleverne opdelt samtidig efter $k \varnothing n$ og efterudskrivelsens art. Over halvdelen af de elever, der udskrives til privatskoler, er piger, ${ }^{14}$ mens man modsat finder, at drengene udgør 90 pct. af de elever, der udskrives til heltidsundervisning $i$ ungdomsskolen ${ }^{15}$ og til erhvervsuddannelse. Dette sidste

Tabel 7. $\S 33-e l e v e r n e ~ 1976-77$ opdelt dels efter $k \varnothing n$ og dels efter udskrivelsens art. Procent

\begin{tabular}{lccccc}
\hline & $\begin{array}{l}\text { Privat- } \\
\text { skole }\end{array}$ & $\begin{array}{l}\text { Efter- } \\
\text { skole }\end{array}$ & $\begin{array}{l}\text { Heltidsund. } \\
\text { i ungdsk. }\end{array}$ & $\begin{array}{l}\text { Erhvervs- } \\
\text { uddan. }\end{array}$ & Arbejde \\
\hline Drenge & 42 & 70 & 90 & 90 & 68 \\
Piger & 58 & 30 & 10 & 10 & 32 \\
\hline I alt & 100 & 100 & 100 & 100 & 100 \\
\hline Gruppernes størrelse & 24 & 33 & 10 & 20 & 84 \\
\hline
\end{tabular}

14) Dette skyldes, som det senere vil blive påvist, at nogle af de elever, der udskrives til privatskolerne, udskrives af helt andre àrsager end $\S 33-e l e-$ verne $i$ ørigt. Denne gruppe har naturligt nok en anden kønssammensætning end $\S 33$-eleverne. Jfr. overvejelserne nedenfor om undervisningsniveau.

15) Af rapporten om heltidsundervisningen $i$ ungdomsskolen fremgår det, at man de næste år har optaget lidt flere piger end tilfældet var i 1976-77, der var det første àr man gennemførte heltidsundervisning i ungdomsskolen i Arhus kommune. I skoleåret 1978-79 var omkring 20 pct. af eleverne piger. (Ivan Hasuser m.fl. (red.), op.cit., p.136). 
afspejler, at det kun er inden for de traditionelle drengefag, at der endnu er mulighed for at skaffe sig en læreplads, hvis man m $\phi-$ der op uden veldokumenterede gode skolekundskaber.

Det er umiddelbart at forvente, at de elever, der udskrives inden afslutningen af 9 års skolegang, er elever, der har haft vanskeligt ved at opfylde de faglige krav, der bliver stillet i folkeskolen. At dette virkelig er tilfældet, fremgår på forskellig vis af denne unders $\phi$ gelse. I tabel 8 er der foretaget en sammenligning mellem $\S 33$-eleverne og hele afgangsårgangen $i$ henseende til under-

Tabel 8. Sammenligning mellem $\S 33$-eleverne og hele afgangsårgangen 1976-77 i henseende til linie (eller kursus). Procent

\begin{tabular}{lcc}
\hline & $\S 33$-elever & Afgangsårgangen \\
\hline Reallinie (udvidet kursus) & 18 & 61 \\
Almenlinie (grundkursus) & 82 & 39 \\
\hline $\mathrm{I}$ alt & 100 & 100 \\
\hline Gruppernes størrelse & 152 & 2668 \\
\hline
\end{tabular}

visningsniveau. ${ }^{16}$ Det fremgår her, som man kunne forvente, at der er uforholdsvis mange elever fra almenlinien blandt $\S 33$-eleverne, nemlig 82 pct., mens almenklasseeleverne kun udg $\phi r 39$ pct. af hele a fgangsårgangen.

Billedet nuanceres noget, hvis man opdeler eleverne efter arten af deres udskrivning og samtidig ser på pigerne og drengene hver for sig. ${ }^{17}$ Dette er gjort $i$ tabel 9. Tabellen viser forst og fremmest to ting. For det første fremkommer der en forskel alt efter, om eleverne udskrives til andre skoleformer (privatskoler, efterskoler), eller om de udskrives til erhvervsmæssia uddannelse eller beskæf-

16) Eleverne er opdelt $i$ to kategorier, hvoraf den ene omfatter reallinieelever og elever, der følger udvidet kursus $i$ sprog og matematik. Den anden kategori onfatter almenlinieelever og elever, der følger grundkursus. Elever, der er udskrevet efter 7 . klasse eller, hvor kursusniveauet er ukendt, er holdt uden for beregningen.

17) På grund af det forholdsvis begrænsede antal elever, der indgảr i beregningen, er kategorierne vedrørende udskrivelsens art blevet slảet sammen, sảledes at kategorien "skole" onfatter de elever, der enten er udskrevet til efterskoler eller til privatskoler. De elever, der er udskrevet til heltidsundervisningen $i$ ungdomsskolen og de to piger, der er udskrevet til erhvervsmassig uddannelse, er ikke medtaget i denne opstilling. Noget tilsvarende er tilfældet $i$ en række af de senere tabeller. 
Tabel 9. $\$ 33-e l e v e r n e ~ 1976-77$ opdelt dels efter linie (kursus) og dels efter udskriveleens art. Selvstændiat for hvert $k \varnothing n$. Procent

\begin{tabular}{l|llc|lc|}
\hline & $\frac{\text { Drenge }}{\text { Skole }}$ & $\begin{array}{l}\text { Erhvervs- } \\
\text { uddan. }\end{array}$ & Arbejde & $\frac{\text { Piger }}{\text { Skole }}$ & Arbejde \\
\hline $\begin{array}{l}\text { Reallinie (udvidet } \\
\text { kursus) }\end{array}$ & 25 & 6 & 4 & 60 & 24 \\
$\begin{array}{l}\text { Almenilinie (grund- } \\
\text { kursus) }\end{array}$ & 75 & 94 & 96 & 40 & 76 \\
\hline I alt & 100 & 100 & 100 & 100 & 100 \\
\hline Gruppernes størrelse & 28 & 18 & 48 & 20 & 21 \\
\hline
\end{tabular}

tigelse. Reallinieandelen er større blandt "de skoleudskrevne" end blandt de "erhvervsudskrevne", idet det først og fremest er privatskolerne, der har aftaget realklasseeleverne. Der er her tale om en lille gruppe af elever, der adskiller sig fra de andre $\S 33-$ elever. Den gennemsnitlige $\S 33$-elev udskrives af folkeskolen, fordi han eller hun har det meget dårligt med skolen. Enkelte udskrivninger har imidlertid en anden begrundelse, nemlig den, at forældrene er bekymrede for, om eleven lærer tilstrækkelig meget $i$ folkeskolen til at kunne klare optagelseskravene til gymnasiet. Egentlig hører denne gruppe elever slet ikke til i en unders $\phi$ gelse af $\S 33$-elever, selv om de formelt er udskrevet efter den samme paragraf. De er alligevel medtaget $i$ unders $\phi$ gelsen, idet det visțe sig meget vanskeligt at finde entydige kriterier, hvorefter man kunne identificere disse elever. Endvidere drejer det sig ikke om nogen særlig stor del af de udskrevne elever, antagelig om noget $i$ retningen af en 10 stykker.

Den anden ting, der fremgår af tabel 9, er forskellen mellem piger og drenge. Drengene kommer $i$ alle grupper of tere fra almenlinien end pigerne. Dette peger $i$ retning af, at de udskrevne drenge oftere end pigerne har haft indlæringsmæssige problemer.

Hvis det er rigtigt, som ovenfor antaget, at $\S 33$-eleverne ofte har haft vanskeligt ved at honorere de faglige krav, der stilles til eleverne $i$ folkeskolen, må man også forvente, at der forholdsvis ofte er blevet iværksat støtteforanstaltninger fra skolens side. 
I tabel 10 er $\S 33$-eleverne blevet sammenlianet med hele afgangsårgangen $i$ henseende $t i l$, om de har deltaget $i$ specialundervisning i løbet af deres skoletid. ${ }^{18}$ Tabellen viser som forventet, at $\S 33-$

Tabel 10. Sammenligning mellem $\S 33$-eleverne og hele afgangsårgangen 1976-77 i henseende til deltagelse i specialundervisning. Procent

\begin{tabular}{lcc}
\hline & $\$ 33$-elever & Afgangsärgangen \\
\hline Specialundervisning & 33 & 17 \\
$\div$ specialundervisning & 67 & 83 \\
\hline I alt & 100 & 100 \\
\hline Gruppernes størrelse & 177 & 177 \\
\hline
\end{tabular}

eleverne forholdsvis ofte har modtaget specialundervisning. Det drejer sig om 33 pct. af disse elever mod kun 17 pct. af samtlige elever. 19

Også $i$ dette tilfælde fremtræder forskellene klarere, hvis man opdeler §33-eleverne efter udskrivelsens art og efter $k \varnothing n$, som det er gjort $i$ tabel 11. Først og fremmest fremkommer der nogle mecet klare kønsforskelle. Ikke mindre end halvdelen af de drenge, der udskrives til erhvervsmæssig beskæftigelse, har fået specialundervisning, som regel $\mathbf{i}$ dansk eller reaning, mens dette kun gælder for 15 pct. af de udskrevne piger. Det er tydeligvis sådan, at de drenge, der udskrives efter $\S 33$, of te har haft problemer $i$ forhold til skolen, der må karakteriseres som indlæringsproblemer. Dette er til gengæld sjældent for pigernes vedkommende. Pigernes problemer må åbenbart have været af anden art.

Tidligere unders $\varnothing$ gelser har peget på, at der er en socialt skæv rekruttering til de tidlige udskrivninger, således at forstå, at det primært er de lavere "socialgruppers" b $\phi \mathbf{r n}$, der udskrives efter

18) Specialundervisning omfatter undervisning i dansk, regning og engelsk. Derimod er de støtteforanstaltninger, der primært er motiveret af adfærdsproblemer ikke $i$ denne forbindelse medtaget som specialundervisning.

19) Egentligkanman undre sig over, at det kun er 33 pct. af de elever, der udskrives pá dispensation inden skolepligtens afslutning, der pá et tidligere tidspunkt $i$ deres skoleforløb har făet tilbudt specialundervisning. 
Tabel 11. § 33-eleverne 1976-77 opdelt efter, om de har deltaget i specialundervisning, og efter uddannelsens art. Selvstændigt for hvert $k \phi n$. Procent

\begin{tabular}{l|llc|lc|}
\hline & $\frac{\text { Drenge }}{\text { Skole }}$ & $\begin{array}{c}\text { Erhvervs- } \\
\text { uddan. }\end{array}$ & Arbejde & $\frac{\text { Piger }}{\text { Skole }}$ & Arbejde \\
\hline Specialundervisning & 39 & 39 & 51 & 13 & 15 \\
* specialundervisning & 61 & 61 & 49 & 87 & 85 \\
\hline I alt & 100 & 100 & 100 & 100 & 100 \\
\hline Gruppernes størrelse & 33 & 18 & 57 & 24 & 27 \\
\hline
\end{tabular}

$\S 33$. Et tilsvarende resultat fremgår af denne undersøgelse. I tabel 12 er der foretaget en sammenligning mellem $\S 33$-eleverne og hele afgangsårqangen $i$ henseende til forældrenes erhverv. ${ }^{20}$ Erhvervsgrupperne er opstillet i rækkefølge således, at man $\phi$ verst har de

Tabel 12. Sammenligning mellem $\S 33$-elever og hele afgangsårgangen 1976-77 i henseende til forældrenes erhverv (moderens erhvervsuddannelse, hvor faderens ikke er kendt). Procent

\begin{tabular}{lcc}
\hline & $\S 33$-elever & Afgangsărgangen \\
\hline Akademikere + pædagoger & 2 & 9 \\
Mellemuddannede funktionærer & 5 & 12 \\
Selvstændige i landbrug & 2 & 5 \\
Selvstændige i byen & 9 & 11 \\
Lavere funktionærer & 13 & 15 \\
Faglærte arbejdere & 21 & 22 \\
Ufaglarte arbejdere & 35 & 18 \\
Uden erhverv & 14 & 7 \\
\hline I alt & 101 & 99 \\
\hline Gruppernes størrelse & 177 & 2693 \\
\hline
\end{tabular}

20) Udgangspunktet for opdelingen har varet faderens erhverv. Hvor faderens erhverv ikke har varet kendt, er moderens anvendt. Kategorien "uden erhverv" omfatter bl.a. enlige mødre uden erhverv. Kategorien "akademikere og prdagoger" er lidt usædvanlig, men den er anvendt i denne undersøgelse, fordi man má formode, at disse grupper har en uddannelsesadfærd, der minder om hinanden, men som adskiller dem fra alle andre grupper. 
erhvervsgrupper, hvis børn er underrepræsenteret blandt $\S 33-e l e-$ verne, mens man nederst har de erhvervsgrupper, hvis børn er overrepræsenteret. Underrepræsenteret blandt $\S 33-\in l e v e r n e$ er b $\phi \mathbf{r n}$ af akademikere, mellemuddannede funktionærer og selvstændige på landet. ${ }^{21}$ Nogenlunde ligeligt repræsenteret $i$ de to grupper er børn af selvstændige $i$ byerne, lavere funktionærer og faglærte arbejdere. Derimod er b $\phi r n$ af ufaglarte arbejdere og b $\phi r n$, hvis forældre er uden erhverv $i$ betydelig grad overrepræsenteret blandt $\S 33-$ eleverne. For de to sidst omtalte grupper gælder det således, at deres børn tilsammen udg $\phi r 25$ pct. af hele afgangsårgangen, mens de udgør hele 50 pct. af $\S 33$-eleverne. Som det ofte er påvist, er det ikke ligegyldigt for ens skolekarriere, hvad ens forældre bestiller.

Ser man imidlertid nærmere på tabel 12, fremgår det, at det nok mere er forældrenes uddannelsesniveau end deres erhverv, der har betydning for, om børnene må afbryde skolegangen inden skolepligtens afslutning. I tabel 13 er der derfor foretaget en sammenligning af forældrenes uddannelsesniveau hos henholdsvis $\S 33$-eleverne

Tabel 13. Sammenligning mellem $\S 33$-elever og hele afgangsårgangen 1976-77 i henseende til forældrenes erhvervsuddannelse (eleven er placeret efter den af forældrene, der har den mest omfattende erhvervsuddannelse). Procent

\begin{tabular}{lcc}
\hline & $\S 33$-elever & Afgangsärgangen \\
\hline Teoretisk uddannelse & 3 & 23 \\
Faglig uddannelse & 31 & 45 \\
Ingen erhvervsuddannelse & 66 & 31 \\
\hline I alt & 100 & 99 \\
\hline Gruppernes størrelse & 177 & 2693 \\
\hline
\end{tabular}

21) I et notat fra 1967 on de tidligt skoleudskrevne kunne Erik Jørgen Hansen pävise, at børn af selvstændige inden for landbruget var stærkt overreprasenteret blandt de elever, der blev udskrevet efter 7 års skolegang. Erik Jørgen Hansens tal relaterer sig imidlertid til et tidspunkt, da skolepligten kun strakte sig over 7 ăr. I landbruget var der tradition for, at børnene gik tidligt ud af skolen. Når eleverne $i$ dag udskrives inden afslutningen af 9 års skolegang, skyldes det ikke som dengang kulturelle traditioner, men egentlige tilpasningsproblemer. (E.J. Hansen, "De tidligt skoleudskrevne", i Betænkning om undervisningspligtens udvidelse, betankning $\mathrm{nr} .473,1968$, pp. $75-80$ ). 
og hele afgangsårgangen. ${ }^{22}$ Resultaterne er endnu tydeligere end $i$ den foregående tabel. Både teoretisk uddannedes og fagligt uddannedes børn er underrepræsenterede blandt $\S 33$-eleverne, mens der findes en betragtelig overrepræsentation af børn, hvis forældre ikke har gennemf $\phi \mathrm{rt}$ nogen erhvervsuddannelse. Børn, hvis forældre har en teoretisk uddannelse, udskrives næsten ikke efter $\S 33$, og de udskrives under ingen omstændigheder til erhvervsmæssig beskæftigelse.

Det er nu blevet påvist, at der dels udskrives uforholdsmæsigt mange elever med indlæringsproblemer, og at der dels udskrives uforholdsmassigt mange elever fra mere uddannelsesfremmede hjem. Man kan nu spørge, hvilken sammenhæng der er mellem disse to ting. Umiddelbart må man nemlig forestille sig, at der er mange børn fra uddannelsesfremmede hjem, der har indlæringsproblemer i folkeskolen. Er det da blot det samme fænomen, der giver sig to forskellige udslag, eller har hver af faktorerne en selvstændig betydning? I tabel 14 kan man se, hvilken betydning hver af faktorerne har for udskrivningsfrekvensen. Samtlige elever i afgangsårgangen er opdelt i 6 grupper efter deres forældres uddannelsesniveau, og efter, om de har fået specialundervisning $i$ folkeskolen. For hver af disse 6 grupper er det beregnet, hvor stor en procentandel, der er udskrevet efter $\S 33$. I parentes er angivet gruppernes størrelse.

Læser man tabellen på den ene led, finder man, at udskrivningsfrekvensen er større for elever, der har fået specialundervisning, end den er for elever, der ikke har, når bortses fra børn af forældre med en teoretisk uddannelse, der stort set slet ikke udskrives efter $\S 33$. Læser man tabellen på den anden led, fremgår det, at udskrivningsfrekvensen både for elever med specialundervisning og for elever uden specialundervisning stiger med faldende uddannelsesniveau blandt forældrene. Børnenes indlæringsproblemer og forældrenes uddannelsesniveau har således hver deres selvstændige betydning for, om eleverne udskrives på dispensation. Tilsammen er deres betydning

22) Ved kategoriseringen af forældrenes uddannelsesniveau er der taget ligeligt hensyn til begge forældres erhvervsuddannelse. Har blot en af forældrene gennemf $\phi r t$ en erhvervsuddannelse, er forældrenes uddannelsesniveau blevet kategoriseret efter denne. Har den ene af forxldrene gennemf $\phi r t$ en teoretisk uddannelse, og den anden har gennemfort en faglig uddannelse, er familiens uddannelsesniveau blevet kategoriseret som "teoretisk uddannelse". Kategorien "teoretisk uddannelse" omfatter $i$ ovrigt stort set alle andre erhvervsuddannelser end faglige uddannelser. 
Tabel 14. Udskrivningsprocenten (efter $\S 33$ ) for grupper af b $\phi r n$ defineret dels ved forældrenes uddannelsesniveau, dels ved, om børnene har modtaget specialundervisning. Tallene $i$ parentes angiver gruppernes størrelse

\begin{tabular}{lrrrr}
\hline & $\begin{array}{l}\text { Ingen } \\
\text { uddan. }\end{array}$ & $\begin{array}{l}\text { Faglig } \\
\text { uddan. }\end{array}$ & $\begin{array}{l}\text { Teoretisk } \\
\text { uddan. }\end{array}$ & Alle \\
\hline Specialundervisning & 238 & 118 & 08 & 158 \\
& $(202)$ & $(215)$ & $(51)$ & $(468)$ \\
† Specialundervisning & 118 & 38 & 18 & 28 \\
& $(647)$ & $(1006)$ & $(572)$ & $(2225)$ \\
\hline Alle & 148 & 48 & 18 & 78 \\
& $(853)$ & $(1221)$ & $(623)$ & $(2693)$ \\
\hline
\end{tabular}

betragtelig. De børn, der kommer fra familier, hvor forældrene ingen erhvervsuddannelse har, og som samtidig selv har indlæringsproblemer, er for omkring en fjerdedels vedkommende blevet udskrevet på dispensation inden skolepligtens afslutning .

Ofte ser man den pastand fremført, at der er forskel på skoler. Nogle skoler er mere villige til at udskrive elever end andre. Ser man på de 40 århusianske skoler, der har leveret elever til denne unders $\phi$ gelse, viser det sig da også, at udskrivelsesfrekvensen varierer meget stærkt. Nogle skoler udskriver slet ikke elever efter $\S 33$, mens andre udskriver omkring 15 pct. af samtlige elever. Ser man alene på udskrivelserne til erhvervslivet, er der nogle skoler, der udskriver over 10 pct. af eleverne. Det er naturligvis ikke tilfaldigt, hvad det er for skoler, der udskriver mange elever. Skolernes geografiske placering, forældregruppens sociale sammensætning og boligmiljøets stabilitet spiller en rolle.

For at belyse dette spørgsmål er de 40 Århus-skoler blevet opdelt $i$ tre lige store grupper efter den uddannelsesmæssige sammensætning af forældrekredsen. I den ene gruppe er samlet de skoler, hvor stort set alle børnenes forældre (faderen eller moderen) har en erhvervsuddannelse. I den anden gruppe er samlet de skoler, hvor omkring $2 / 3$ af b $\phi$ rnenes forældre har en erhvervsuddannelse. Og endelig er i den sidste gruppe samlet de skoler, hvor kun omkring halv- 
delen af forældrene har en erhvervsuddannelse. ${ }^{23}$ Ved erhvervsuddannelse forstås $i$ denne sammenhæng både teoretiske og faglige uddannelser. Denne opdeling af skolerne efter forældrenes uddannelsesniveau svarer nogenlunde til den opdeling, man ville fă, hvis man foretog en geografisk opdeling af skolerne. Ser man på de skoler, hvor forældrekredsen har det laveste uddannelsesniveau, viser det sig, at de dels er placeret i det indre af Århus by, dels $i$ de yderområder af kommunen, hvor der $i$ de seneste år er foretaget meget omfattende lejlighedsbyggerier, og hvor der endnu er en forholdsvis lav grad af boligmæssig stabilitet. Omvendt gælder det for de skoler, hvor forældrene har et højt uddannelsesniveau, at de allesammen er placeret $i$ en tæt kreds rundt om Århus by. Der er tale om gamle villakvarterer og nyere parcelhuskvarterer, i begge tilfælde meget stabile boligkvarterer.

Tabel 15. Udskrivningsprocenten (efter $\S 33$ ) i tre forskellige skoletyper, karakteriseret ved den uddannelsesmæsige sammensætning af forældrekredsen

Pct, udskrevet Pct. udskrevet Gruppernes efter $\S 33$ efter $\S 33$, størrelse stk, 4

Skoler, hvor forældrenes uddannelsesniveau er højt $2,5 \quad 0,8$ 842 Skoler, hvor forældrenes uddannelsesniveau er middelhøjt $6,6 \quad 4,1$ 945 Skoler, hvor formldrenes uddannelsesniveau er lavt

10,4 6,4 906

23) De tre grupper onfatter hver følgende skoler: A) Skoler hvor forældrenes uddannelsesniveau er højt: Engdalsskolen, Gammelgaardsskolen, Hasle skole, Jellebakkeskolen, Katrinebjergskolen, Kragelundskolen, Risskov skole, Rosenvangsskolen, Rundhøjskolen, Strandskolen, Sфlystskolen, Vejlby skole, Viby skole. B) Skoler hvor forældrenes uddannelsesniveau er middelhøjt: Aaby Skole, Elsted skole Fjordsgades skole, Gjellerupskolen, Hasselager skole, Holme skole, Læssøesgades skole, Malling skole, Skovvangsskolen, Skødstrup skole, Skæring skole, Tranbjerg skole, vestergärdsskolen. c) Skoler hvor forældrenes uddannelsesniveau er lavt: Bakkegärdsskolen, Brobjergskolen, Finsensgades skole, Frydenlundsskolen, Møllevangsskolen, Nordgärdskolen, Ny Munkegades skole, Næshфjskolen, Sabro-Korsvejskole, Søndervangskolen, Tilst skole, Vorrevangskolen. Kategoriseringen er foretaget efter helt andre principper, men stemmer alligevel meget godt overens med den opdeling, der er foretaget $i$ Martin $R \phi-$ mer, Ib Andersen og Peter Møller, Skolevejlederen og parg. 33 i folkeskoleloven, Danmarks Lxrerhøjskole 1978. Resultaterne svarer sáledes cgsà meget godt til hinanden. 
Tabel 15 viser udskrivningsfrekvensen dels generelt efter $\S 33$, dels specielt efter $\$ 33$, stk. 4, for hver af de tre forskellige skoletyper. Ikke uventet finder man stigende udskrivningsfrekvenser med faldende uddannelsesniveau i skolernes forældrekreds. Specielt er der markante forskelle med hensyn til udskrivningerne til erhvervslivet efter $\S 33$, stk. 4 .

Nu kunne man stille det spørgsmål, om resultaterne i tabel 15 ikke blot er en gentagelse af de resultater, der allerede er blevet vist $i$ tabel 13, nemlig at udskrivningen $i \mathrm{~h} \phi j$ grad er bestemt af forældrenes uddannelsesniveau? Problemet er altså, om skolemiljøet har en selvstændig betydning for udskrivningsfrekvensen. Dette spørgsmål kan belyses, hvis man inden for hver af de tre skoletyper opdeler eleverne efter forældrenes uddannelsesniveau og ser på udskrivningsfrekvenserne for børn med ensartet forældrebaggrund. Dette er gjort $\mathbf{i}$ tabel 16, idet der både er opgivet den samlede udskrivningsfrekvens for $\S 33$ og den specielle for $\S 33$, stk. 4 .

Tabel 16. Sammenhængen mellem forældrenes erhvervsuddannelsesniveau og udskrivningen efter $\S 33$, særskilt for tre forskellige skoletyper

Skoler, hvor forældrenes uddan-

nelsesniveau er højt

Forælare med teoretisk uddan. $0,3 \quad 0,0 \quad 319$

$\begin{array}{llll}\text { Forældre med faglig uddan. } & 1,4 & 0,5 & 370\end{array}$

Foraldre uden uddan.

9,8

3,3

153

Skoler, hvor forældrenes uddannelsesniveau er middelhojt

$\begin{array}{llll}\text { Forældre med teoretisk uddan. } \quad 1,0 & 0,0 & 210\end{array}$

Forældre med faglig uddan. $\quad 3,8 \quad 2,0 \quad 449$

Forældre uden uddan.

15,0

10,5

286

Skoler, hvor forældrenes uddannelsesniveau er lavt

Forældre med teoretisk uddan.

Forældre med faglig uddan.

3,0

0,0

94

Forældre uden uddan.

8,0

4,7

402

Alle

14,4

9,5

410

Alle

6,6

3,9

2693 
Tabellen viser klart, at skolemiljøet har en selvstændig betydning, og at mønsteret er det samme, hvad enten man ser pa alle udskrivningerne eller kun på udskrivningerne til erhvervslivet. Ser vi eksempelvis på udskrivningerne til erhvervslivet, fremgår det, at ingen af skoletyperne udskriver børn af forældre, der har en teoretisk uddannelse. Forskellene fremkommer imidlertid, når man ser på børn af forældre, der har en faglig uddannelse. På de skoler, hvor forældrene gennemgående har et højt uddannelsesniveau, udskrives der kun en halv procent af disse børn, mens der udskrives 2 pct. fra de skoler, hvor forældrene har et middelt uddannelsesniveau, og 5 pct. fra de skoler, hvor forældrene gennemgående har et lavt uddannelsesniveau. Følger man tilsvarende udskrivningsfrekvenserne for de børn, hvis forældre ikke har nogen erhvervsuddannelse, får man, at der på de skoler, hvor forældrene gennemgående har et højt uddannelsesniveau, udskrives omkring 3 pct., mens der på de to andre typer skoler udskrives omkring 10 pct. Det er altså ikke blot uddannelsesniveauet hos børnenes egne forældre, der betyder noget for udskrivningen, - også skolemiljøet har en selvstændig betydning. 24

Disse forskelle mellem skolerne skal antagelig forklares ved to forhold. For det første har mængden af problemer på en skole i sig selv en forstærkende effekt på de eksisterende problemer. Er der $i$ forvejen $i$ en klasse samlet mange børn med skoleproblemer, vil det være vanskeligt for både børn og lærere at klare nye problemer. Mange problembørn skaber således flere problembørn. En anden ting er, at de høje udskrivningsfrekvenser antagelig har en selvstændig indvirkning på skolens ledelse. På nogle skoler bliver udskrivning efter $\S 33$ næsten en rutinesag, idet der i gennemsnit ekspederes en udskrivning på hvert skolenævnsmøde. På andre skoler udskriver man $h \phi j s t$ et eller to børn om året. Her bliver udskrivning en stor sag. Dette har antagelig en selvstændig betydning for både lærernes og skolenævnenes villighed til at udskrive børn inden skolepligtens udløb. Både over for børnene, lærerne og skolens ledelse har mængden af problemer altså en forstærkende effekt.

24) Antagelig kan mangà endnu videre og sige, at det er det sociale miljø i bred forstand, der spiller en rolle for udskrivningsfrekvenserne. Det er skolemiljøet, men også boligmiljøet, og hvad dermed følger af fxlles holdninger over for uddannelse $i$ forældrekredsen. (Der er i øvrigt foretaget en yderligere kontrol af dette resultat, idet analysen er blevet gentaget, mens pá én gang forældrenes erhvervsuddannelse og forældrenes øjeblikkelige erhverv blev holdt konstant. Ogsá denne analyse bekræftede eksistensen af miljøforskelle). 
4. Hvordan er det gået? Beskæftigelsessituationen to år efter udskrivelsen

Når man diskuterer anvendelsen af $\S 33$, er det vel nok mest centrale spфrgsmål, hvorledes det er gået eleverne, efter at de er blevet udskrevet af folkeskolen. Det springende punkt er, om det er til skade eller til gavn for det enkelte barn at blive udskrevet. For at give et fuldgyldigt svar på dette spørgsmål skulle man ideelt set vide, hvorledes det var gået barnet, hvis det ikke var blevet udskrevet. Det kan man naturligvis ikke sige noget om på grundlag af denne undersøgelse. ${ }^{25}$ Men det er muligt at sige noget om, hvordan det faktisk er gået eleverne, og på grundlag heraf er det så igen muligt at drøfte, om det opnåede resultat er tilfredsstillende.

I tabel 17 er $\S 33$-eleverne blevet opdelt efter deres beskæftigelse $i$ december 1978, det vil sige omkring 2 år efter, de har forladt folkeskolen på dispensation, og deres beskæftigelse er blevet sammenlignet med hele afgangsårgangens. For $\S 33$-eleverne som helhed gælder det, at 43 pct. er 1 gang med en eller anden form for uddannelse, heraf 30 pct. med en erhvervsuddannelse. 43 pct. har u-

Tabel 17. En sammenligning mellem $\S 33$-eleverne og hele afgangsårgangen 1976-77 $i$ henseende til beskæftigelse $i$ december 1978. Procent

\begin{tabular}{lcc}
\hline & $\S 33$-elever & Afgangsårgangen \\
\hline Gymnasiet/HF & 2 & 32 \\
Anden skole & 11 & 4 \\
Erhvervsuddannelse & 30 & 37 \\
Arbejde & 42 & 19 \\
Arbejdsløs & 11 & 5 \\
Husmor & 4 & 1 \\
Svg, andet, værnepligtig & 1 & 2 \\
\hline I alt & 101 & 100 \\
\hline Gruppernes størrelse & 141 & 2326 \\
\hline
\end{tabular}

25) Skulle man gøre det, ville det kræve en undersøgelse med en kontrolgruppe af elever, der ikke blev udskrevet pả dispensation, men hvis forhold i øvrigt svarede til de udskrevne elevers. 
faglært arbejde, 11 pct. er arbejdsløse og 4 pct. er husmødre. Ved vurderingen af denne sidste kategori, "husmødre", må man lige erindre sig, hvilken alder eleverne havde på unders $\varnothing$ gelsestidspunktet. De piger, der her er registreret som husmødre, var i dec. 1978 enten 16 eller 17 år gamle. I vore dages samfund anses det normalt ikke for en tilfredsstillende beskæftigelse for en 17-årig pige at være husmor. I det følgende vil derfor de arbejdsløse og husm $\varnothing$ drene blive slået sammen til én kategori, omfattende de tidligere elever, der hverken er $i$ gang med en uddannelse eller har et arbejde.

Sammenligner man derpå $\S 33$-elevernes beskæftigelse med hele afgangsårgangens, forekommer der nogle karakteristiske forskelle. Først og fremmest frekventerer omkring en trediedel af hele årgangen gymnasiet eller HF, mens det kun gælder 2 pct. af $\S 33$-eleverne. Omvendt er kun 19 pet. af afgangsårgangen beskæftiget ved ufaglært arbejde, mens det gælder 42 pct. af $\S 33$-eleverne. 6 pct. af afgangsårgangen er uden beskæftigelse, mens det gælder 15 pct. af $\S$ 33-eleverne. Sammenlignet med hele afgangsårgangen har $\S 33$-eleverne altså klaret sig markant dårligere.

Det er nok også noget urimeligt at sammenligne §33-eleverne med hele afgangsårgangen, da deres forudsætninger i så mange henseender er ringere. Mere relevant er det antagelig at sammenligne $\S 33$-elevernes beskæftigelsessituation med situationen for de elever, der er gåt ud af almenlinien. Billedet bliver endvidere klarere, hvis man betragter pigegruppen og drengegruppen hver for sig. I tabel 18 er der derfor for piger og drenge hver for sig blevet foretaget en sammenligning mellem $\S 33$-eleverne, alle almenlinieelever og hele afgangsårgangen. Dette skulle give et bedre perspektiv på § 33-elevernes beskæftigelsessituation.

Ser man først på drengegruppen, fremgår det, at der er betydelige forskelle mellem $\S 33$-elevernes beskæftigelsessituation og de andre almenklasse-drenges. Mens lige ved to trediedele af alle almenklassedrengene er $i$ gang med en erhvervsuddannelse, gælder det kun omkring en trediedel af $\S 33$-drengene. Omvendt er kun 26 pct. af alle almenklasse-drengene beskæftiget ved ufaglært arbejde, mens dette gælder 43 pct. af $\S 33$-drengene. Også arbejdsløshedsprocenten er større blandt $\S 33$-drengene, idet den er på 9 pct., mod 6 pct. for alle almenklasse drenge. Alt i alt må man således sige, at det er gået § 33-drengene dårligere end de $\varnothing$ vrige almenklasse-drenge. Især 
Tabel 18. Sammenligning mellem $\S 33$-eleverne, elever på almenlinien og hele afgangsårgangen 1976-77 i henseende til beskæftigelse i dec. 1978, særskilt for hvert køn. Procent

\begin{tabular}{|c|c|c|c|c|c|c|}
\hline & $\begin{array}{l}\frac{\text { Drenge }}{\$ 33-} \\
\text { elever }\end{array}$ & $\begin{array}{l}\text { Almen li- } \\
\text { nie ele. }\end{array}$ & $\begin{array}{l}\text { Hele afg. } \\
\text { årg. }\end{array}$ & $\begin{array}{l}\frac{\text { Piger }}{\$ 33-} \\
\text { elever }\end{array}$ & $\begin{array}{l}\text { Alinen li- } \\
\text { nie ele. }\end{array}$ & $\begin{array}{l}\text { Hele afg. } \\
\text { arg. }\end{array}$ \\
\hline Gymnasiet/HF & 1 & 2 & 29 & 5 & 2 & 35 \\
\hline Anden skole & 9 & 2 & 4 & 15 & 6 & 5 \\
\hline Erhvervsuddan. & 37 & 63 & 46 & 12 & 34 & 28 \\
\hline Arbejde & 43 & 26 & 15 & 39 & 38 & 22 \\
\hline Arbejdsløs/husmor & 9 & 6 & 3 & 29 & 20 & 9 \\
\hline Andet & 1 & 2 & 2 & 0 & 1 & 1 \\
\hline I alt & 200 & 101 & 99 & 100 & 101 & 100 \\
\hline Gruppernes størrelse & 100 & 464 & 1162 & 41 & 354 & 1163 \\
\hline
\end{tabular}

er de sjældnere kommet $i$ gang med en erhvervsuddannelse. Dette kan til en vis grad skyldes, at de er yngre end de andre almenklasseelever, men det kan. næppe begrunde den store forskel.

Ser man dernæst på pigerne, bliver billedet endnu mørkere. Kun 12 pct. af $\S 33$-pigerne er kommet $i$ gang med en erhvervsuddannelse, mens 20 pct. går i gymnasiet eller på en anden skole. Om disse sidste piger gælder det, at de fleste tilhører den gruppe, der som tidligere omtalt, er gået fra reallinien til en privatskole, og som kun 1 formel forstand tilhører gruppen af $\S 33$-elever. videre er

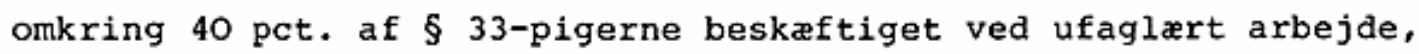
mens ikke mindre end 30 pct, er uden beskæftigelse, idet de er arbejdsløse eller husm $\phi$ dre.

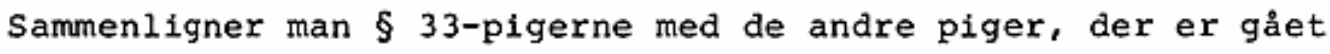
ud af almenlinien, er forskellen måske nok mindre end den var for de tilsvarende grupper af drenge. Men dette skyldes, at det også er gået de andre almenklassepiger rigtigt dårligt. Det er ganske vist et sidespring $i$ denne forbindelse, men det er alligevel vard at bemærke, at kun 40 pct. af almenklasse-pigerne er $i$ gang med et uddannelsesforl $\varnothing \mathrm{b}$, og at ikke mindre end 20 pct. af dem er uden beskæftigelse. Dette er en meget stærk dokumentation af, at det nuværende danske uddannelsessystem har meget lidt at tilbyde piger, der ikke er $i$ stand til at qennemf $\phi$ re en realeksamen. 
Sammenligner man til sidst pigerne og drengene fra $\S 33$-gruppen er forskellen også markant. 29 pct. af pigerne er arbejdsløse mod 9 pct. af drengene. 12 pct. af pigerne er kommet 1 gang med en erhvervsuddannelse mod 37 pct. af drengene. § 33-drengenes beskæftigelsessituation er således nok dårlig, men den er dog langt bedre end de tilsvarende pigers. Hvordan kan man forklare dette? For det første er årsagen den gammelkendte, at der endnu inden for mandsfag findes erhvervsuddannelser, hvor der ikke stilles store krav til lærlingenes skolekundskaber. Tilsvarende uddannelser inden for kvindefag eksisterer så at sige ikke. Dernæst er der et særligt problem, der hedder graviditet og børnefødsler. De piger, der karakteriserer sig selv som husmødre, har antagelig et barn at passe, men det gælder helt sikkert også flere af de andre $\S 33$-piger. Et rimeligt gæt vil være, at $i$ hvert fald 20 pct. af disse $\S 33-p i g e r$ er gravide eller har fået et barn, inden de er fyldt 18 år. Dette har utvivlsomt ikke forbedret deres muligheder i uddannelsessystemet og på arbejdsmarkedet. Endelig kan der være grund til at vende tilbage til nogle af de overvejelser, der blev fremført $i$ det foregående afsnit, nemlig at der var forskel på de problemer, der lå bag henholdsvis pigers og drenges udskrivning af folkeskolen. For drengenes vedkommende havde der $i$ stort omfang været tale om indlæringsproblemer, mens dette ikke var særlig fremtrædende for pigernes vedkommende. For pigernes vedkommende var der snarere tale om generelle tilpasningsproblemer, ringe selvtillid, dårlige samarbejdsevner, dårlig kammeratkontakt, dårlig voksenkontakt, og en umådelig passivitet. For en del af drengenes vedkommende kan man derfor håbe på, at de vil trives bedre med de anderledes krav, de vil blive stillet over for uden for folkeskolen. For pigernes vedkommende er der overhovedet ingen baggrund for et sådant håb.

De netop fremf $\phi$ rte overvejelser falder godt i tråd med de synspunkter, der er blevet fremført af Tine Bryld, at en del af de svagest udrustede piger $i$ den nuværende krisesituation flygter ind i familie og børn for på denne måde at skabe sig en identitet, de ikke er $i$ stand til at skabe gennem uddannelse og erhverv. Talmaterialet må siges at være meget spinkelt, men det er alligevel påfaldende, at 12 pct. af $\S 33$-pigerne karakteriserer sig selv som 
husmødre, mens det samme kun gælder for 1 pct. af de $\phi v r i g e$ piger $^{26}$

- specielt når man tager $i$ betragtning, at $\S 33$-pigerne $i$ gennemsnit er mindst et år yngre end de andre piger.

I dette afsnit er $\S 33$-eleverne indtil nu blevet behandlet under et uden hensyn til arten af udskrivelse. Imidlertid vil det være interessant at se, om der er forskel på, hvorledes det er gået de elever, der udskrives til andre skoleformer og til erhvervslivet. En sådan opdeling er, særskilt for piger og drenge, foretaget i tabel 19 .

Tabel 19. $\S 33-e l e v e r n e ~ 1976-77$ opdelt efter beskæftigelsen i december 1978 og efter udskrivelsens art, særskilt for hvert $k \varnothing n$. Procent

\begin{tabular}{l|ccc|cc|}
\hline & $\frac{\text { Drenge }}{\text { Skole }}$ & $\begin{array}{l}\text { Erhvervs- } \\
\text { uddan. }\end{array}$ & Arbejde & $\frac{\text { Piger }}{\text { Skole }}$ & Arbejde \\
\hline Skole & 35 & 0 & 2 & 35 & 5 \\
Erhvervsuddannelse & 35 & 81 & 25 & 20 & 5 \\
Arbejde & 23 & 19 & 59 & 25 & 50 \\
Arbejdsløs/husmor & 8 & 0 & 12 & 20 & 40 \\
\hline I alt & 101 & 100 & 98 & 100 & 100 \\
\hline Gruppernes størrelse & 26 & 16 & 51 & 20 & 20 \\
\hline
\end{tabular}

Tabel 19 skærper forståelsen for, hvad det er for elever, der klarer sig dårligt, efter at de har forladt folkeskolen. De drenge, der udskrives for at påbegynde en erhvervsuddannelse, synes gennemgående at klare denne qodt. De fleste af drengene er stadigvæk to år efter $i$ gang med en erhvervsuddannelse, mens en enkelt har afsluttet sin. Videre gælder det om de elever, der er blevet overført til andre skoleformer, at de tilsyneladende har klaret sig lige så godt (eller skidt) som de фvrige elever, der er blevet udskrevet af almenlinien. Dette skal ses i sammenhæng med det forhold, at de elever, der udskrives af folkeskolen til andre skoleformer, antagelig

26) Et yderligere belæg for dette synspunkt bliver givet i Ulrik Thomassens artikel, "Uddannelsessystemets restgruppe og ungdomsarbejdsløsheden". Det fremgär her, at 18 pct. af alle 22 og 24 àrige piger er hjemmegáende husm $\phi d r e$, mens det kun gælder 3 pct. af dem, der havde gennemført en erhvervsuddannelse. (Tidsskriftet Politica, dette $\mathrm{nr}$.). 
har befundet sig dårligere i folkeskolen end de andre almenklasseelever. Set i denne sammenhæng må man sige, at det er ganske godt, at deres beskæftigelsessituation er lige så god som de andre almenklasseelevers. Udskrivning til andre skoleformer synes således of te at være en god idé.

Til gengæld må man konstatere, at situationen for de elever, der blev udskrevet til erhvervsmæssig beskæftigelse, er så meget desto mørkere. For drengenes vedkommende er der først og fremmest problemer med at komme igang med en erhvervsuddannelse. Derimod er deres arbejdsløshed ikke større end, man kunne forvente, når man tager $i$ betragtning, hvor stort et antal der er arbejdssфgende. Man skal imidlertid nok passe på ikke at overvurdere disse drenges muligheder på arbejdsmarkedet. De fleste af dem var på unders $\varnothing$ gelsestidspunktet under 18 år, og man kan derfor frygte, at de kun klarer sig $i$ kraft af deres unge alder. Man ved, at mange job er lukkede den dag, de unge bliver 18 år, og det er næppe helt galt, når man antager, at det netop er nogle af disse job § 33-drengene bestrider. Stort set må det dog siges at være positivt, at drengene for de flestes vedkommende er i beskæftigelse og således endnu ikke har mistet kontakten til arbejdsmarkedet.

Til gengald har lige ved halvdelen af pigerne mistet kontakten til arbejdsmarkedet. Det mest positive, man kan sige om pigernes situation, er vel nok, at det er så forholdsvis få piger, der udskrives til erhvervsmæssig beskæftigelse. Derudover er der intet positivt at tilføje. Den ene halvdel er uden beskæftigelse, og den anden halvdel arbejder ufaglært - antagelig i job, der lukker sig for dem, når de fylder 18 år. Igen kan der være grund til at advare mod det spinkle talgrundlag, idet man dog samtidig må erindere, at unders $\phi$ gelsen dækker alle de elever, der er udskrevet efter $\S 33$ i Århus kommune i skoleåret 1976-77. Når talgrundlaget er spinkelt skyldes det altså, at der ikke blev udskrevet flere elever.

\section{Hvordan det i фvrigt er gået $\S 33$-eleverne}

I folkeskolekredse støder man af og til på den bekymring, at det at udskrive elever til andre skoleformer blot er det første skridt på vejen til en egentlig udskrivning til erhvervslivet. Det kan derfor være væsentligt at få at vide, hvorledes det skolemæsigt går de elever, der er udskrevet til andre skoleformer. Lykkes det dem 
uden for folkeskolens rammer at gennemføre de ni års skolegang? Dette spфrgsmål kan man få besvaret ved at se på, om $\S 33$-eleverne har bestået nogle af de prøver eller eksaminer, der anvendes som afslutning på det 9. og 10. skoleår. ${ }^{27}$ I tabel 20 er $\S 33$-eleverne opdelt $i$ tre kategorier, hvoraf den første omfatter de elever, der har afsluttet deres skolegang med en prøve eller eksamen, den anden omfatter de elever, der uden at have aflagt en prøve stadigvæk går $i$ skole, mens den tredie kategori omfatter de elever, der har afsluttet skolegangen uden prфve. Opgфrelsen er foretaget særskilt for de elever, der er udskrevet til andre skoleformer, og for dem, der er udskrevet til erhvervslivet.

Tabel 20. $\$ 33$-eleverne 1975-76 opdelt efter, om de har bestået nogle af folkeskolens prøver, og efter udskrivelsens art

\begin{tabular}{lcc}
\hline & skole & Arbejde \\
\hline $\begin{array}{l}\text { Ingen eksamen/prøve og gàr ikke } \\
\text { langere } \mathbf{i} \text { skole }\end{array}$ & 11 & 94 \\
$\begin{array}{l}\text { Ingen eksamen/prøve, men går } \\
\text { stadig i skole }\end{array}$ & 11 & 3 \\
Har bestäet prøve, eksamen & 78 & 3 \\
\hline I alt & 100 & 100 \\
\hline Gruppernes størrelse & 46 & 72 \\
\hline
\end{tabular}

Som man kunne forvente, er der så at sige ingen af de elever, der er blevet udskrevet til erhvervslivet, der senere er vendt tilbage til skolen og har afsluttet skolegangen med en prøve eller eksamen. Mere interessant er det, at langt det overvejende flertal af de elever, der blev udskrevet til andre skoleformer, er fortsat med skolegangen disse steder, således at det kun er 11 pct., der har forladt skolen uden en eller anden form for prøve eller eksamen. Og af de 11 pct., der har forladt skolen uden prøve eller eksamen, er der utvivlsomt et mindre antal, der har fortsat skolegangen til afslutningen af det 9. eller 10. skoleår, uden at de derfor har været $i$ stand til at opfylde kravene til den statskontrollerede prøve. Blandt landets efterskoler findes der således nogle, der helt be-

27) Det drejer sig om realeksamen, statskontrolleret prøve efter 9. klasse og efter 10. klasse, teknisk forberedelseseksamen og folkeskolens afgangsprøver. 
vidst ikke fører deres elever frem til prøver eller eksaminer.

For de fleste af de elever, der udskrives til andre skoleformer, gælder det altså, at det lykkes dem at gennemf $\varnothing$ re 9 års skolegang, blot ikke inden for folkeskolens rammer. Det er nok også det, der er baggrunden for, at det går dem nogenlunde lige så godt som de andre almenklasseelever.

Det blev $i$ det foregånde afsnit fremhavet, at kun en mindre del af $\S 33$-eleverne var kommet $i$ gang med en erhvervsuddannelse. Imidiertid var de fleste af de unders $\phi$ gte elever endnu ikke fyldt 18 år på unders $\varnothing$ gelsestidspunktet. De har således stadig muligheder for at komme $i$ gang med en erhvervsuddannelse. Deres chancer er antagelig ikke særlig store, men nogle muligheder eksisterer der. En første forudsætning må imidlertid være, at de unge selv har forestillinger eller фnsker om en sådan erhvervsuddannelse. Fra andre unders $\varnothing$ gelser ved man, at så at sige alle unge, i hvert fald på det tidspunkt da de forlader skolen, har et $\varnothing$ nske om at gennemf $\varnothing$ re en eller anden erhvervsuddannelse. Sp $\phi$ rgsmålet er, om $\S 33-$ eleverne også har et sådant фnske, eller om deres hidtidige erfaringer med skolen og med erhvervslivet har været af en sådan art, at de helt har opgivet sådanne $\varnothing$ nsker.

I tabel 21 er dels $\S 33$-eleverne, dels hele afgangsårgangen opdelt $i$ tre kategorier. Den første omfatter de unge, der er $i$ gang med en erhvervsuddannelse. Den anden omfatter de unge, der uden at være $i$ gang med en uddannelse har en forestilling om, at de vil påbegynde en $i$ løbet af de kommende 2-3 år. Og den tredie kategori omfatter de unge, der hverken er $i$ gang med eller har ønsker. om at komme i gang med en uddannelse. Opgørelsen er, som tidligere, foretaget særskilt for piger og drenge. ${ }^{28}$ Igen er det forskellen mellem de to $k \phi n$, der falder $i$ '́jnene. For drengenes vedkommende gælder det, at næsten alle $\S 33$-eleverne har planer om at gennemføre en erhvervsuddannelse. Kun 21 pct. giver ikke udtryk for sădanne фnsker. Man kan dog have sine tvivl om, hvor realistiske disse fremtidsplaner er. For pigerne derimod ser det anderledes ud, idet omkring halvdelen af pigerne erklærer, at de ikke har ønsker

28) Spørgsmålet er desværre ikke blevet stillet til de piger, der har karakteriseret sig selv som husmødre, hvorfor disse er holdt uden for beregningerne i denne tabel. Var disse piger blevet inddraget var resultatet antagelig blevet endnu varre. 
om en erhvervsuddannelse. Denne forskel er så meget desto mere markant, som piger generelt har lige så omfattende фnsker om erhvervsuddannelse som drenge. Færre piger end drenge fra afgangsårgangen er ganske vist kommet $i$ gang med en erhvervsuddannelse, men til gengæld ønsker så mange desto flere at komme $i$ gang med nogen inden for de næste år. § 33-pigerne udgør her en undtagelse. De har så at sige allerede opgivet ævred. De ved godt, at de aldrig nogen sinde får en erhvervsuddannelse.

Benedicte Madsen skriver $i$ artiklen "Om de unges fremtidsplaner,

Tabel 21. Sammenligning mellem $\S 33$-eleverne og hele afgangsårgangen 1976-77 i henseende til ønsker om erhvervsuddannelse, samlet og særskilt for hvert $k \phi n$. Procent

\begin{tabular}{|c|c|c|c|c|c|c|}
\hline & $\begin{array}{l}\frac{\text { Alle }}{\S 33-} \\
\text { elever }\end{array}$ & $\begin{array}{l}\text { Afgangs- } \\
\text { árgangen }\end{array}$ & $\begin{array}{l}\frac{\text { Drenge }}{\$ 33-} \\
\text { elever }\end{array}$ & $\begin{array}{l}\text { Afgangs- } \\
\text { árgangen }\end{array}$ & $\begin{array}{l}\frac{\text { Piger }}{533-} \\
\text { elever }\end{array}$ & $\begin{array}{l}\text { Afgangs- } \\
\text { årgangen }\end{array}$ \\
\hline $\begin{array}{l}\text { Er } i \text { gang med en er- } \\
\text { hvervsuddannelse }\end{array}$ & 32 & 38 & 38 & 46 & 15 & 29 \\
\hline $\begin{array}{l}\text { Ønsker at komme i gang } \\
\text { med en erhvervsuddan. }\end{array}$ & 40 & 47 & 41 & 38 & 36 & 56 \\
\hline $\begin{array}{l}\text { Har intet фnske on er- } \\
\text { hvervsuddannelse }\end{array}$ & 28 & 15 & 21 & 15 & 48 & 16 \\
\hline I alt & 100 & 100 & 100 & 99 & 99 & 101 \\
\hline Gruppernes størrelse & 131 & 2253 & 98 & 1132 & 33 & 1121 \\
\hline
\end{tabular}

ledighed og beskæftigelsesarbejde", ${ }^{29}$ at det er meget vigtigt for de unges identitetsdannelse, at de har fremtidsplaner, og videre at det er tilsvarende rigtigt, at de unges $\varnothing j$ jeblikkelige beskæftigelse kan ses som led $i$ udfoldelsen af denne fremtidsplan. I vort samfund er planer om erhvervsuddannelse en vigtig del af de unges fremtidsplaner, og det gælder både for drenge og for piger. § 33pigerne er imidlertid ikke $i$ gang med at realisere fremtidsplaner om en erhvervsuddannelse. Og de fleste af dem har helt opgivet den slags planer, hvis de nogensinde har haft dem. De må derfor sфge at skabe sig en identitet på en anden måde, gennem mand og børn.

29) Tidsskriftet Politica, dette nr. 


\section{Sammenfatning}

Der er vel ingen, der mener, at der er noget positivt i, at udskrive elever efter folkeskolelovens $\S 33$. Men mange har alligevel en forestilling om, at det $i$ konkrete tilfælde kan være til gavn for det enkelte barn at komme væk fra en folkeskole, hvor det befinder sig dårligt, og komme i gang med noget andet, der passer bedre til dets forudsætninger og interesser.

Skal man på grundlag af denne unders $\phi$ gelse konkludere noget om, hvad der er til gavn for børnene, er det nфdvendigt at sondre mellem de forskellige former for udskrivning. Der indgår $i$ unders $\phi$ gelsen meget få elever, der er udskrevet efter $\S 33$, stk. 3 til heltidsundervisning $i$ ungdomsskolen. Denne form for udskrivning vil det derfor ikke være muligt at sige noget særskilt om. ${ }^{30}$ Derimod vil det være muligt at sige noget om de to andre hovedformer, udskrivning efter $\S 33$, stk. 2 til andre skoleformer og udskrivning efter $\S 33$, stk. 4 til erhvervsmæsig beskæftigelse.

Om de elever, der udskrives til andre skoleformer, viser undersфgelsen, at det går dem nogenlunde så godt, som man kunne håbe. Langt de fleste af disse elever afslutter deres skolegang med at aflægge en af folkeskolens prøver. Og deres beskæftigelsessituation er omkring to år efter, at de har forladt folkeskolen, nogenlunde lige så god som årgangens andre almenklasseelever. Dog skal man nok tage $i$ betragtning, at $\S 33$-eleverne gennemgående er yngre end de andre elever fra afgangsårgangen, hvorfor der er grund til at frygte, at deres situation vil forværres, når de $i$ løbet af det følgende år fylder 18 år. Alt $i$ alt må man dog sige, at en udskrivning til andre skoleformer forekommer at være et rimeligt alternativ for de elever, der befinder sig dårligt i folkeskolen. Under alle omstændiqheder er det en meget bedre løsning end at udskrive eleverne til erhvervsmæssig beskæfigelse.

Anderledes skidt går det de elever, der udskrives til erhvervsmæsig beskeftigelse. En meget lille del af drengene og så at sige ingen piger er kommet $i$ gang med en erhvervsuddannelse to år efter

30) I rapporten fra heltidsundervisningen i ungdomsskolen konkluderer man vedrørende arbejdet $i$ frhus kommune: "Det falder ikke særlig let, at vurdere resultaterne af Hu-arbejdet. Det er svært at vide, hvorledes det ville være gáet eleverne, hvis de ikke var kommet til hu: Elevernes tilkendegivelse foranlediger os til at tro, at en del af arbejdet lykkes. Hjemmene siger det samme." (Ivan Häuser m.fl. (red.), op.cit., p. 136). 
udskrivningen. Drengene er for størstedelens vedkommende stadigvæk beskæftiget med ufaglært arbejde, mens pigerne for lige ved halvdelens vedkommende er uden beskæftigelse. Disse elever hører nok til dem, der har befundet sig særlig dårligt i folkeskolen. Alligevel må man sige, at udskrivningen næppe har forbedret deres situation.

Specielt for pigernes vedkommende har udskrivningen været problematisk. En stor del af de udskrevne drenge har haft indlæringsmæssige problemer i skolen. De har specielt haft svært ved at opfylde kravene $i$ den boglige folkeskole. Disse indlæringsproblemer har utvivlsomt også givet sig udslag $i$ adfardsproblemer. Alligevel har de fleste af disse drenge været $i$ stand til at klare de praktiske krav, de er blevet stillet overfor uden for skolen. De er således stadigvæk erhvervsmæssigt beskæftiget. Pigerne derimod har ikke været særligt præget af indlæringsproblemer. De har blot i almindelighed haft svært ved at klare sig blandt de andre elever $i$ skolen. De har hellier ikke kunnet klare kravene $i$ de ufaglærte job, de begyndte på, da de forlod skolen. Har deres selvtillid været ringe tidligere, er den blot blevet endnu mindre. Halvdelen af alle § 33-pigerne har opgivet at få en uddannelse. Og det gælder for en endnu større andel af dem, der er udskrevet efter stk. 4. Oven $i$ det hele har nogle af dem tillagt sig børn. Hverken disse piger eller deres børn har store chancer for at klare sig fremover.

Hvilke konklusioner kan man da draqe af denne meget pessimistiske vurdering af, hvorledes det er gået de elever, der udskrives efter folkeskolelovens $\S 33$, stk. 4 til erhvervsmæssig beskæftigelse? Konklusionen er ikke, at man skal fors $\phi$ ge at beholde disse elever $i$ folkeskolen. Alt tyder på, at de kun har fået et meget begrænset udbytte af folkeskolens undervisning. Konklusionen er snarere, at det er nødvendigt at tilbyde dem andre former for undervisning, helst undervisning der minder så lidt som muligt om folkeskolens undervisning. Heltidsundervisningen $i$ ungdomsskolen er én mulighed, efterskolerne er en anden. Rundt omkring $i$ landet foretages der $i$ $\varnothing j$ jblikket et stort antal eksperimenter med at kombinere praktisk arbejde med teoretisk undervisning. De bedste af disse eksperimenter har antagelig noget at tilbyde de elever, der $i$ dag udskrives efter $\S 33$, stk. 4 .

Alligevel vil det nok ikke være muligt helt at undga at foretage 
udskrivninger til erhvervsmæssig beskæftigelse. Det mindste, man kan gøre for disse elever, er da at tilbyde dem en omfattende rådgivning og vejledning om beskæftigelsesmuligheder og uddannelsesmuligheder, også efter at de er blevet udskrevet af skolen. I Århus kommune blev der i sommeren 1978 indført en såkaldt "udvidet skolevejleder-ordning", der indebærer, at skolevejlederne kontakter de udskrevne elever regelmæssigt inden for de første to år, efter de har forladt folkeskolen, og tilbyder dem råd og vejledning, hvis de synes at have brug for det. $\S 33$-eleverne bliver imidlertid f $\phi$ rst inddraget $i$ denne ordning pả det tidspunkt, da deres skolepligt oph $\phi-$ rer, hvilket $i$ de værste tilfalde vil sige op til to år efter, at eleverne er blevet udskrevet af skolen. På dette tidspunkt vil det antagelig være alt for sent for skolevejlederen at foretage sig noget som helst. $\S 33$-eleverne bør naturligvis tilbydes vejledning på det tidspunkt, hvor de har mulighed for at drage nytte af den, nemlig når de forlader skolen. Og dette tilbud om støtte og vejledning må antagelig være mere omfattende end det, der gives til folkeskolens andre elever.

Eleverne kan kun udskrives til erhvervsmæssig beskæftigelse efter folkeskolelovens $\S 33$, stk. 4, "når særlige grunde taler for, at det er til elevens bedste". Det må skolen således have skønnet, var tilfældet, hver eneste gang den udskrev elever efter denne paragraf og dette stykke. Har skolens vurdering været rigtig, må man imidlertid på grundlag af de fremlagte resultater konkludere, at det der var til "elevens bedste" under ingen omstændigheder viste sig at være godt nok. Det'er derfor nфdvendigt, at man har andet at tilbyde de skoletrætte elever.

Artiklen meddeler resultater fra en unders $\varnothing$ gelse af en gruppe børn, der på grundlag af folkeskolelovens $\S 33$ er udskrevet pä dispensation inden afslutningen af 9 års skolegang. Artiklen belyser $i$ hovedsagen tre spørgsmäl, nemlig spørgsmálet om udskrivelsernes omfang, spørgsmálet om hvad det er for elever der udskrives og endelig spørgsmálet om, hvorledes det går eleverne efter udskrivelsen. Artiklens hovedkonklusion er, at det specielt om de elever, der bliver udskrevet efter $§ 33$, stk. 4 til erhvervsmassig beskæftigelse, gælder, at de klarer sig meget dảrligt efter udskrivelsen. Dette peger pá nødvendigheden af, at der skabes relevante undervisningstilbud, der kan fungere som alternativ til en udskrivelse. 